\title{
Interpretation and Use of Penetrometer Data to describe Soil Compaction in Vineyards.
}

\author{
L. VAN HUYSSTEEN \\ Viticultural and Oenological Research Institute, Private Bag X5026, \\ 7600 Stellenbosch, Republic of South Africa.
}

The author wishes to express his thanks and appreciation to Miss A. E. Theron for her technical assistance.

Submitted for publication: May 1983

Accepted for publication: September 1983

\begin{abstract}
A portable recording penetrometer was used for in situ field measurements of soil strengths in existing experiments with known profile characteristics. The data reported include effects of soil preparation methods, tractor wheel compaction and soil moisture on soil strength, as well as a case study in a production vineyard. The penetrometer proved to be a useful instrument in identifying and quantifying soil compaction problems and the effects of soil management systems in vineyards. The data revealed that serious subsoil compaction can exist which may result in very poor vine performance and even death of the vines.
\end{abstract}

It is well-known that the soil physical environment is of great importance for optimum plant growth. Therefore, there is a need to describe or to quantify optimum soil physical conditions or the effects of different management practices. According to Cassel, Bowen \& Nelson (1978), a systematic measurement of soil physical properties, unlike chemical properties, and subsequent recommendations for modification has not been achieved on a routine basis.

Soil strength or mechanical impedance is one physical parameter that can be used to assess the soil's suitability for root growth and function. Taylor, Robertson \& Parker (1966) reported that any change in soil strength, due either to compaction or to a change in soil moisture characteristics, may cause a change in root growth. Penetrometer resistance (or cone index) is used to provide a relative measure of the resistance offered by soil to the penetration of roots, and is expressed as the ratio between the force required to push a metal cone into a soil versus the basal area of the cone (Davidson, 1965).

Root-restricting soil layers, with high mechanical impedance, can thus be identified with a suitable penetrometer. The soil offers a greater resistance to penetration of a metal cone than to roots. One of several reasons for this difference is that the penetrometer, unlike the root, cannot deviate from the direct line of advance when a resistant aggregate is encountered (Marshall \& Holmes, 1979). The utility of mechanical resistance as a measure of soil strength, as well as its variability, was thoroughly investigated by Cassel \& Nelson (1979). They concluded that although a wide range of variation may exist, penetrometer data can be validly interpreted and used to assess soil strength and soil management effect thereon, provided that selected data transformation and analysis are done.

The difficulties in making an unambiguous interpretation of the relationship between penetrometer resistance and plant growth is mentioned by Cassel et al. (1978). Considerable research effort has been expended in an attempt to relate penetrometer resistance to soil physical properties such as texture, depth, bulk density and soil moisture content (Taylor \& Gardner, 1963; Gill \& Vanden Berg, 1968; Bradford, 1980), with varying results. The importance of probe design standardization was stressed by Bradford (1980). There is a critical, albeit ill-defined, soil strength above which root penetration is seriously hindered - generally reported in literature as $2000-2500 \mathrm{kPa}$ for various crops and probes (Zimmerman \& Kardos, 1961; Taylor \& Gardner, 1963; Taylor \& Burnett, 1964; Greacen, Barley \& Farrell, 1969; Bar-Yosef \& Lambert, 1981).

Against the background of the above the following objectives were set out for this study:

(i) To evaluate the effect of viticultural soil management systems by comparing profiles of penetrometer resistance.

(ii) To make a contribution towards the quantification of soil compaction in vineyards by means of simple in situ soil strength measurements.

\section{MATERIALS AND METHODS}

The portable recording penetrometer utilized in this study was developed and described by Carter (1967). The apparatus was used with two interchangeable $30^{\circ}$ included-angle polished steel cones with areas of $1,29 \mathrm{~cm}^{2}$ and $3,22 \mathrm{~cm}^{2}$, as specified by the ASAE (1969). Although cone resistance was shown to be relatively insensitive to penetration rate (Waldron \& Constantin, 1970), great care was taken to maintain continuous insertion at the ASAE recommended rate of approximately $1,83 \mathrm{~m} \mathrm{~min}^{-1}$. When stones were encountered the rate of penetration tended to drop and then momentarily rose to a high value after the stone had been pushed aside. Such a position was abandoned and a new one selected.

Penetrometer measurements were made in the field in existing field trials on sites where profiles had previously been studied. At the time of the penetration test the soil water content of all sites was approximately equal to the 
in situ field water capacity. At least ten randomly selected positions were taken at each plot to represent a particular treatment.

All data are presented graphically so as to provide profiles of soil strength against depth for different treatments. A soil strength of $2000 \mathrm{kPa}$ was provisionally accepted as the critical value at which root growth becomes seriously impeded. Values submitted to statistical analysis were the maximum soil strength occurring within each arbitrarily chosen depth as suggested by Cassel et al. (1978).

\section{Penetrometer resistances were measured and evaluated as follows:}

- A comparison of five methods of soil preparation was made in an existing soil preparation trial on a Glenrosa soil of granitic origin, Kanonkop series (Soil classification according to MacVicar et al., 1977), on the experimental farm, Nietvoorbij, of the Viticultural and Oenological Research Institute near Stellenbosch. Treatments applied:

- Diagonal double delved to a depth of $100 \mathrm{~cm}$.

- Wing ploughed to a depth of $100 \mathrm{~cm}$.

- Wing ploughed to a depth of $75 \mathrm{~cm}$.

- Single direction delved to a depth of $100 \mathrm{~cm}$.

- Shallow ploughed to a depth of $45 \mathrm{~cm}$.

The implements used were described by Saayman \& Van Huyssteen (1981). The penetrometer readings were taken four months after the soil had been worked, levelled, planted to vines and the trellising system was erected. These penetrometer data were also compared to soil strengths measured four years after planting in order to determine soil consolidation.

- A study was undertaken at Groot Constantia to quantify the compacting effect of tractor wheels after passage over a Clovelly soil (granitic parent material),
Southwold series (MacVicar et al., 1977), which had been deep ploughed to a depth of $60 \mathrm{~cm}$ immediately prior to measurement.

- Penetrometer measurements were also conducted in a soil cultivation experiment described by Van Huyssteen \& Weber (1980) and in a soil preparation trial reported by Saayman \& Van Huyssteen (1980), but in which deep soil loosening between the tractor tracks was done with a wiggle plough (Van Huyssteen \& Saayman, 1980).

- The effect of soil moisture on soil strength was assessed in an irrigation trial on a Hutton soil - Shigalo series (MacVicar et al., 1977) - at Robertson where exact moisture determinations were regularly done.

- The decline of a thirteen year old Colombar vineyard grafted on $99 \mathrm{R}$ on a farm near Bonnievale, which started dying from its eleventh year in ever enlarging patches (Fig. 1) was investigated. This Sterkspruit soil, Swaerskloof series (MacVicar et al., 1977), was ripped only in one direction before the vineyard was planted in 1968, and was clean cultivated and flood-irrigated ever since. Measurements of soil strength were supplemented by in situ bulk density determinations with a rubber balloon apparatus (Van Huyssteen \& Weber, 1980), a particle size analysis and a chemical analysis of soil samples taken from both normal and problem sites in the vineyard.

\section{RESULTS AND DISCUSSION}

Soil preparation: The effect of different soil preparation practices on soil strength is shown in Fig. 2, while the maximum soil strength readings with depth for the same treatments are presented in Table 1. Double delving reduced soil strength at all depths to values less than those measured for any other soil preparation method (Fig. 2).

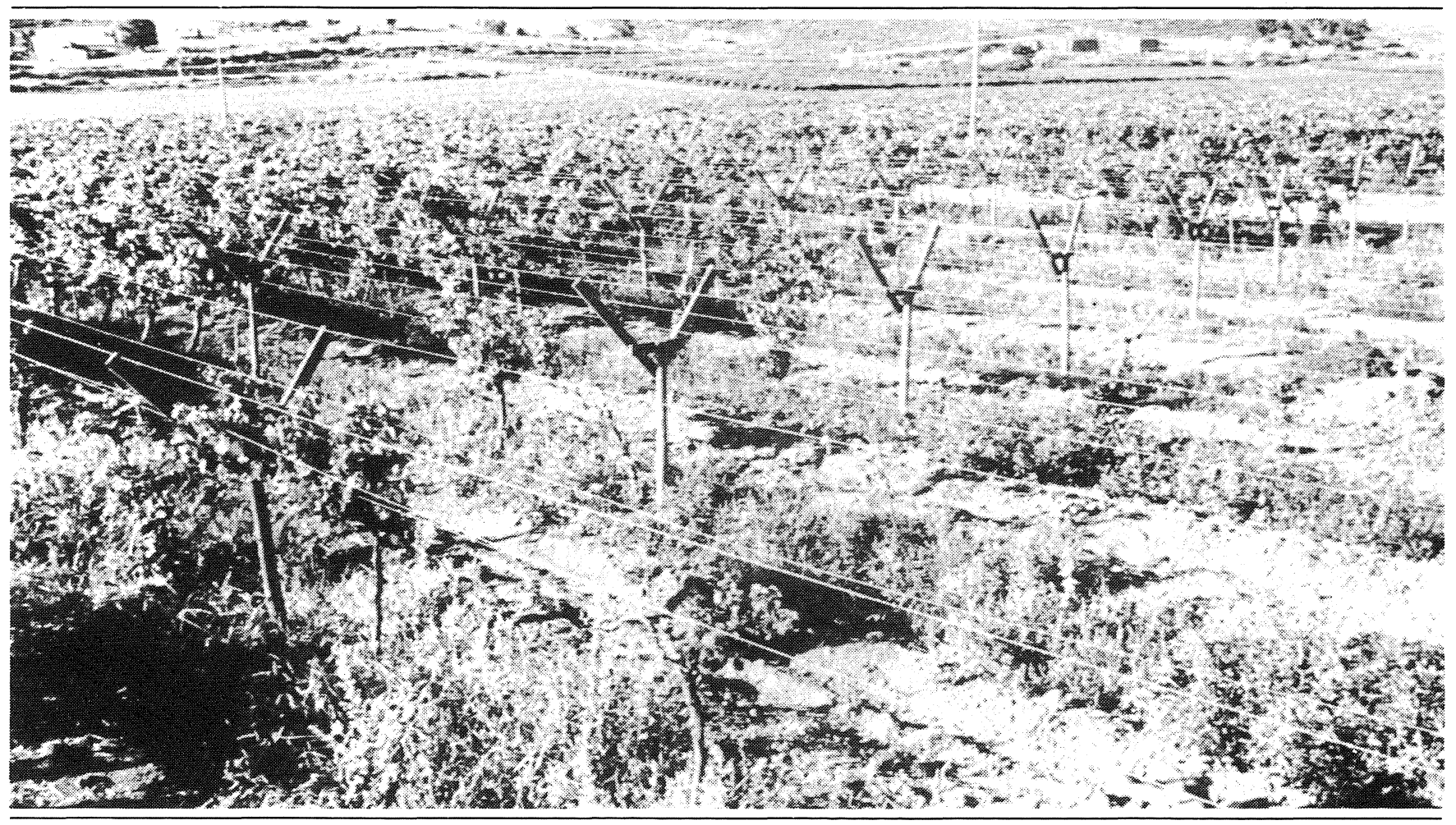

FIGURE 1

Colombar/99R vineyard near Bonnievale which started dying in patches. 
Mixing and breaking up of the compact soil by deep single direction (DSD) delving was inadequate, however, and this showed significant greater soil strengths at all depths than the double delve treatments (Table 1). Furthermore, penetrometer resistances measured at the $0-30 \mathrm{~cm}$ depth were significantly higher after DSD delving than for the other soil preparation methods, except in the case of shallow ploughing. These unexpectedly high soil strengths at shallow depths on the DSD delved plots are due to the formation of big clods (Schulte-Karring, 1976) which were broken up, however, by double delving.

TABLE 1

Maximum soil strengths per horizon as affected by soil preparation methods - Nietvoorbij.

\begin{tabular}{|c|c|c|c|c|c|c|c|}
\hline \multirow[t]{2}{*}{$\begin{array}{l}\text { Depth } \\
(\mathrm{cm})\end{array}$} & \multicolumn{5}{|c|}{$\begin{array}{l}\text { Soil strengths }\left(\mathrm{kPa} \times 10^{2}\right) \text { for the } \\
\text { different treatments }\end{array}$} & \multirow{2}{*}{$\begin{array}{l}\text { Significance } \\
\text { (D-value at } \\
P \leqslant 0,05)\end{array}$} & \multirow[t]{2}{*}{$\begin{array}{l}\mathrm{CV} \\
\%\end{array}$} \\
\hline & 1 & 2 & 3 & 4 & 5 & & \\
\hline $0-30$ & 10,07 & 10,83 & 10,75 & 23,61 & 15,08 & 10,11 & 55,7 \\
\hline $30-60$ & 6,14 & 10,29 & 11,50 & 18,10 & 25,84 & 9,83 & 53,6 \\
\hline $60-90$ & 11,35 & 24,98 & 28,00 & 28,00 & 28,00 & 11,72 & 33,6 \\
\hline
\end{tabular}

1 Double delved to a depth of $100 \mathrm{~cm}$.

2 Wing ploughed to a depth of $100 \mathrm{~cm}$.

3 Wing ploughed to a depth of $75 \mathrm{~cm}$.

4 Single direction delved to a depth of $100 \mathrm{~cm}$.

5 Shallow ploughed to a depth of $45 \mathrm{~cm}$.

$\mathrm{CV}$ Coefficient of variation.

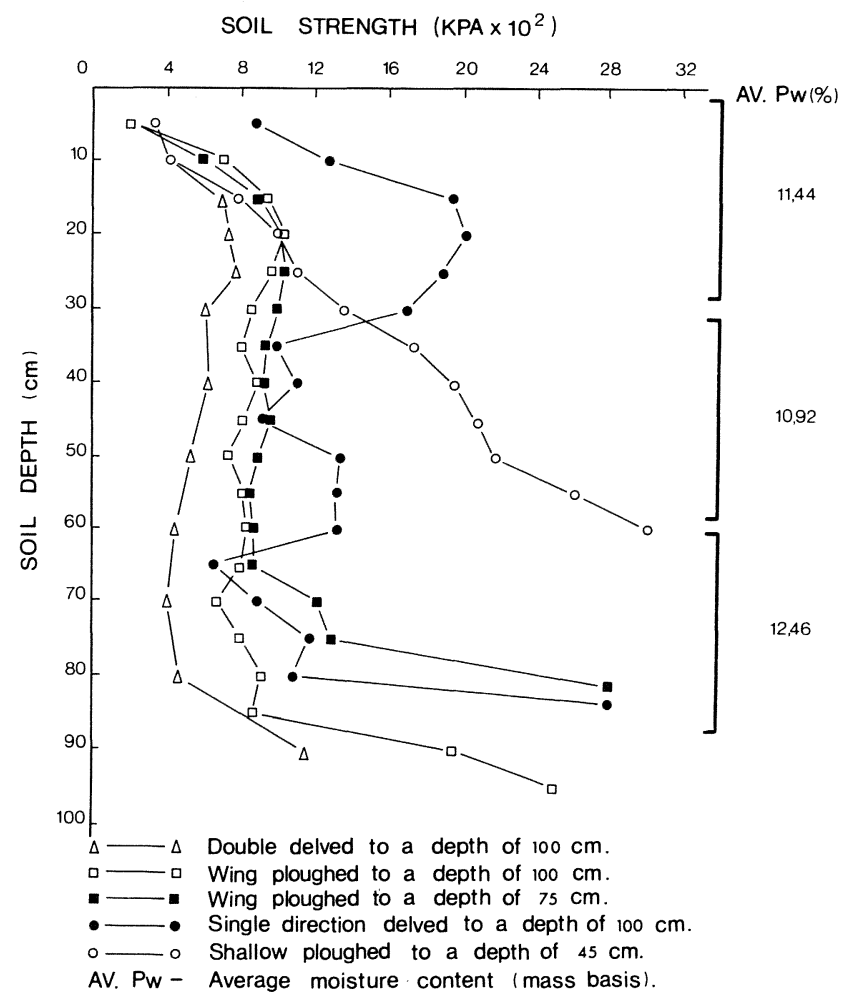

FIGURE 2

Effect of different soil preparation methods on penetrometer resistance - Glenrosa soil, Nietvoorbij.

The wing plough yielded only slightly less favourable soil strengths than double delving (Fig. 2). However, despite good loosening of the soil, this method cannot at present be recommended for soil preparation where an ameliorant such as lime is required in the subsoil because of ineffective distribution (Saayman \& Van Huyssteen, 1981).

Penetrometer measurements (Fig. 2; Table 1) clearly indicated that shallow ploughing was totally ineffective in creating a favourable root environment in the subsoil, as was also concluded by Saayman \& Van Huyssteen (1980).

The exceptionally high coefficient of variation for the penetrometer readings (Table 1 ) might be ascribed to the high percentage of coarse fraction (2-6 $\mathrm{mm}$ diam.) in this soil (Table 2) and to the fact that only the maximum soil strength values within a horizon were analysed.

TABLE 2

Textural analysis of a Glenrosa soil - Nietvoorbij.

\begin{tabular}{|c|c|c|c|c|c|c|}
\hline \multirow{2}{*}{$\begin{array}{l}\text { Depth } \\
\text { (cm) }\end{array}$} & \multirow{2}{*}{$\begin{array}{l}\% \\
\text { Coarse } \\
\text { frag- } \\
\text { ments } \\
(2-6 \mathrm{~mm} \varnothing)\end{array}$} & \multicolumn{5}{|c|}{ Particle size analysis on soil fraction } \\
\hline & & $\begin{array}{l}\text { Coarse } \\
\text { Sand } \\
(2,0- \\
0,5 \mathrm{~mm})\end{array}$ & $\begin{array}{l}\text { Medium } \\
\text { Sand } \\
(0,5- \\
0,2 \mathrm{~mm})\end{array}$ & $\begin{array}{l}\text { Fine } \\
\text { Sand } \\
(0,2- \\
0,02 \mathrm{~mm})\end{array}$ & $\begin{array}{l}\text { Silt } \\
(0,02- \\
0,002 \\
\mathrm{~mm})\end{array}$ & $\begin{array}{l}\text { Clay } \\
(<0,002 \\
\mathrm{mm})\end{array}$ \\
\hline $0-30$ & 26,90 & 17,66 & 19,18 & 35,02 & 16,32 & 11,41 \\
\hline $30-60$ & 29,32 & 18,20 & 9,69 & 22,91 & 15,87 & 32,50 \\
\hline $60-90$ & 19,98 & 16,13 & 8,25 & 20,71 & 16,06 & 37,74 \\
\hline
\end{tabular}

Another interesting and important observation was that the effective working depth was about $20-25 \%$ less than the length of the shanks due to the soil lift effect.

Results obtained with the penetrometer were confirmed by bulk density values (Table 3 ), which also indicated generally lower values for the double delved and wing ploughed treatments. However, the superiority of the penetrometer method in evaluating the efficiency of soil preparation methods was demonstrated by the fact that clods on the DSD delved plots could not be detected with bulk density determinations because triplicate determinations at only one "representative" position per plot were done. The ease and rapidity of penetrometer measurements (10-15 positions per plot can easily be handled) compared to the time-consuming bulk density determinations leave no doubt regarding the choice of methods.

TABLE 3

Bulk densities as affected by different soil preparation techniques Nietvoorbij.

\begin{tabular}{rlccccc} 
Depth (cm) & \multicolumn{5}{c}{ Bulk densities $\left(\mathrm{kg} \cdot \mathrm{m}^{-3}\right)$ for the different treatments } \\
\cline { 2 - 6 } & \multicolumn{1}{c}{2} & \multicolumn{2}{c}{2} & 3 & 4 & 5 \\
\hline $0-25$ & - & 1505,4 & 1413,3 & 1483,3 & 1363,0 \\
$25-50$ & 1260,8 & 1528,0 & 1477,3 & 1437,1 & 1479,6 \\
$50-75$ & 1475,0 & 1518,0 & 1383,1 & 1559,1 & 1748,5 \\
$75-100$ & 1331,6 & 1443,3 & 1502,9 & 1687,9 & 1755,5 \\
$>100$ & 1741,7 & 1657,4 & 1632,6 & 1748,2 & 1744,1 \\
\hline $\bar{X}$ & 1452,3 & 1530,4 & 1481,8 & 1583,1 & 1618,1 \\
\hline
\end{tabular}

1 - Double delved to a depth of $100 \mathrm{~cm}$

2 - Wing ploughed to a depth of $100 \mathrm{~cm}$

3 - Wing ploughed to a depth of $75 \mathrm{~cm}$

4 - Single direction delved to a depth of $100 \mathrm{~cm}$

5 - Shallow ploughed to a depth of $45 \mathrm{~cm}$.

Recompaction: The increase in soil strength due to soil consolidation between the tractor tracks on the deep ploughed plots after four years is illustrated in Fig. 3. Part of this recompaction is caused by the mass of the overlaying soil. At this stage the natural consolidation was still below the critical value of $2000 \mathrm{kPa}$. A series of 


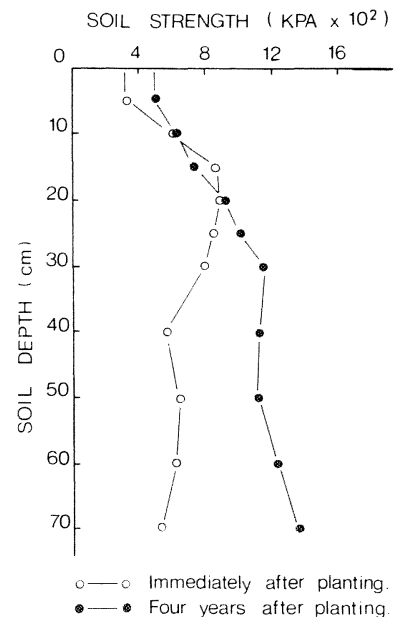

FIGURE 3

Consolidation of deeply loosened soil as measured between the tractor tracks - Glenrosa soil, Nietvoorbij.

SOIL STRENGTH $\left(\mathrm{KPA} \times 10^{2}\right)$

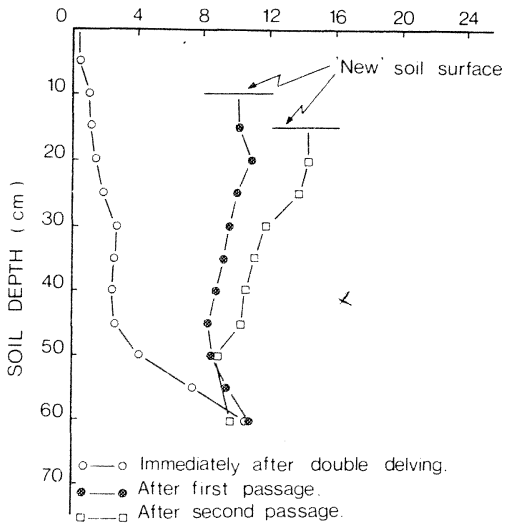

FIGURE 4

Compaction by tractor wheels on a Clovelly soil immediately after loosening - Groot Constantia.

(a)

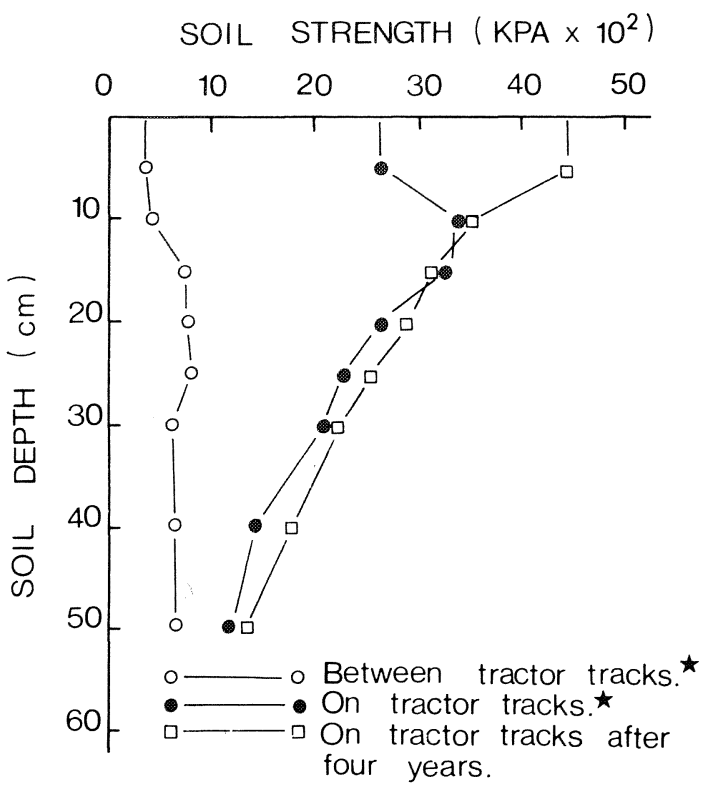

* After four months. such curves obtained at regular time intervals after establishment of a vineyard might be useful to determine when the soil needs a secondary loosening action as described by Van Huyssteen \& Saayman (1980).

The effect of standard wheel tractors normally used in vineyards on soil compaction is quite marked (Fig. 4; Table 4). The first passage of the tractor wheels over the loose soil caused a highly significant increase in soil strength down to a depth of $45 \mathrm{~cm}$. The second passage had a significant effect in the $0-15 \mathrm{~cm}$ depth only. The compactive force of the tractor wheels was also manifested in the change in soil surface. The $15 \mathrm{~cm} \mathrm{(25 \% )}$ drop in the surface level of the soil meant that the same mass of soil was compacted into a smaller volume resulting in higher bulk densities and soil strengths. Further proof of the serious compactive effect of tractor wheels is illustrated in Fig. 5 (a \& b). Most of the damage was done within the first four months after planting of the vineyard (Fig. 5(a)), even under conditions of minimum cultivation. Therefore, wheel tractors should not be used in vineyards for at least one year after planting in order to allow roots to penetrate the whole soil volume. On a Clovelly soil, with a high compactibility (Van Huyssteen \& Weber, 1980), under continuous mechanical cultivation very high soil strengths were measured throughout the soil profile on the tractor tracks (Fig. 5(b)). In this case the compacted area, with high mechanical impedance under the tracks, formed a very effective barrier to lateral root growth (Schulte-Karring, 1976). Deep root growth was impeded because the subsoil was also very compact, due to shallow soil preparation (Van Huyssteen \& Weber, 1980).

Deep loosening of soils in existing vineyards is sometimes necessary to overcome the effects of recompaction (Van Huyssteen \& Saayman, 1980). The effect of such loosening between vine rows is shown in Fig. 6. In this case the soil was effectively loosened from track to track (b)

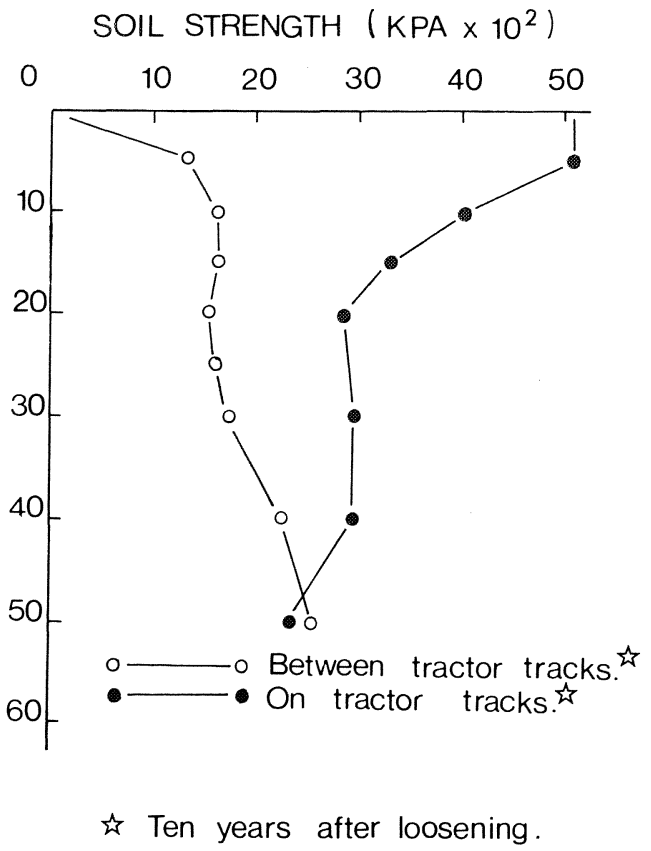

FIGURE 5

Damage by tractor wheels on two soil types: (a) Glenrosa, and (b) Clovelly - Nietvoorbij. 
TABLE 4

Maximum soil strengths per horizon before and after passage of tractor - Groot Constantia.

\begin{tabular}{|c|c|c|c|c|c|}
\hline \multirow[t]{2}{*}{$\begin{array}{l}\text { Deptha) }^{\text {a) }} \\
(\mathrm{cm})\end{array}$} & \multicolumn{3}{|c|}{$\begin{array}{l}\text { Soil strengths }\left(\mathrm{kPa} \times 10^{2}\right) \\
\text { for different treatments }\end{array}$} & \multirow{2}{*}{$\begin{array}{l}\text { Significance } \\
\text { (D-value at } \\
P \leqslant 0,05\end{array}$} & \multirow[t]{2}{*}{$\begin{array}{l}\mathrm{CV} \\
(\%)\end{array}$} \\
\hline & 1 & 2 & 3 & & \\
\hline $0-15$ & 1,13 & 11,18 & 15,06 & 1,45 & 12,2 \\
\hline $15-30$ & 2,73 & 9,76 & 11,25 & 1,90 & 18,4 \\
\hline $30-45$ & 3,00 & 9,56 & 10,46 & 2,63 & 26,2 \\
\hline $45-60$ & 10,56 & 13,16 & 11,40 & NS & 28,3 \\
\hline
\end{tabular}

a) Depth measured from "new" soil surface.

1 - Measured immediately after ploughing.

2 - Measured after first passage of tractor.

3 - Measured after second passage of tractor.

$\mathrm{CV}$ - Coefficient of variation

NS - Not Significant

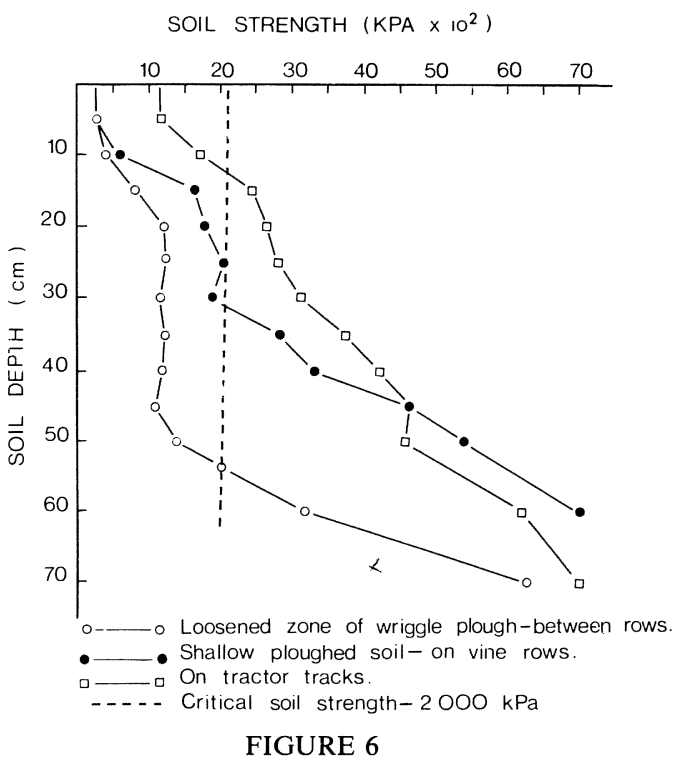

Penetrometer resistance as measured across the vine row on a shallow ploughed soil - Robertson. to a depth of $55 \mathrm{~cm}$. This will enable ramification of the few existing roots which are cut, and of new roots which can grow through the cracks created by the wiggle plough through the compacted tractor tracks (SchulteKarring, 1976).

Soil moisture: Soil strength increased drastically with a decrease in soil moisture content as illustrated in Fig. 7 for the Robertson soil and as also reported by Cassel et al. (1978) and Bradford (1980). Therefore, it is important to do penetrometer tests only in soils with a moisture content close to field capacity, as was the case with the measurements reported here. The high soil strengths encountered within the $0-15 \mathrm{~cm}$ depth show the tendency of this specific soil towards crust formation. Eavis \& Payne (1970) stressed the importance of soil water for root growth since they noted that as the soil dried out, higher soil strengths became evident through distortions in the root systems. In order to keep soil strengths below the threshold value an adequate soil moisture content during the periods of active root growth (Oct./Nov. and after harvest) is important to promote root development.

Case study: Textural and chemical soil analysis of normal as well as problem patches in a vineyard at Bonnievale which started dying in patches (Fig. 1) are summarized in Table 5 . Texturally the only significant difference between the soils was the $10 \%$ higher fine sand fraction in the subsoil from the problem patches and the percentage of coarse fragments. The bulk densities in the subsoil of the problem patches were much higher than those of the normal patches. It is unlikely that the higher salinity of the subsoil of the problem areas could have caused the death of the vines, because it is highly unlikely for a vine to die of brack without showing the classical leaf symptoms. The reason for the lower $\mathrm{P}$ - and $\mathrm{K}$-content of the problem

TABLE 5

Textural and chemical analysis of a Sterkspruit soil near Bonnievale

a) Textural density $(\zeta$ b) determinations

\begin{tabular}{|c|c|c|c|c|c|c|c|c|}
\hline \multirow[t]{2}{*}{ Profile position } & \multirow[t]{2}{*}{ Depth $(\mathrm{cm})$} & \multirow{2}{*}{$\begin{array}{l}\% \text { Coarse } \\
\text { fragments } \\
(2-6 \mathrm{~mm} \emptyset)\end{array}$} & \multicolumn{5}{|c|}{ Particle size analysis on soil fraction $<2 \mathrm{~mm} \emptyset$} & \multirow{2}{*}{$\begin{array}{l}\zeta \mathrm{b} \\
\left(\mathrm{kg} \cdot \mathrm{m}^{-3}\right)\end{array}$} \\
\hline & & & $\begin{array}{l}\text { Coarse } \\
\text { Sand } \\
(\%)\end{array}$ & $\begin{array}{l}\text { Medium } \\
\text { Sand } \\
(\%)\end{array}$ & $\begin{array}{l}\text { Fine } \\
\text { Sand } \\
(\%)\end{array}$ & $\begin{array}{l}\text { Silt } \\
(\%)\end{array}$ & $\begin{array}{l}\text { Clay } \\
(\%)\end{array}$ & \\
\hline \multirow[t]{2}{*}{ Problem area } & $0-55$ & 20,8 & 2,58 & 5,38 & 43,12 & 24,58 & 24,38 & 1561,5 \\
\hline & $55-110$ & 64,3 & 1,77 & 4,71 & 43,33 & 22,98 & 29,44 & 1859,9 \\
\hline \multirow[t]{2}{*}{ Normal area } & $0-55$ & 53,3 & 2,31 & 6,31 & 43,03 & 22,31 & 26,82 & 1429,0 \\
\hline & $55-110$ & 41,7 & 2,35 & 5,09 & 33,43 & 26,92 & 31,02 & 1620,7 \\
\hline
\end{tabular}

b) Chemical analysis

\begin{tabular}{|c|c|c|c|c|c|c|c|c|}
\hline \multirow[t]{3}{*}{ Profile position } & \multirow[t]{3}{*}{ Depth $(\mathrm{cm})$} & \multicolumn{7}{|c|}{ Measured soil property } \\
\hline & & \multirow{2}{*}{$\begin{array}{l}\mathrm{pH} \\
(\mathrm{KC} 1)\end{array}$} & \multirow{2}{*}{$\begin{array}{l}\text { Rs } \\
\text { (ohm) }\end{array}$} & \multirow{2}{*}{$\begin{array}{l}\text { Bray P } \\
\text { (ppm) }\end{array}$} & \multicolumn{4}{|c|}{ Total extractable cations (me \%) } \\
\hline & & & & & $\mathrm{Na}$ & $\mathrm{K}$ & $\mathrm{Ca}$ & $\mathrm{Mg}$ \\
\hline \multirow[t]{2}{*}{ Problem area } & $0-55$ & 7,6 & 788 & 52 & 0,51 & 0,27 & 12,39 & 2,86 \\
\hline & $55-110$ & 6,6 & 231 & 35 & 1,62 & 0,49 & 5,14 & 3,28 \\
\hline \multirow[t]{2}{*}{ Normal area } & $0-55$ & 7,8 & 658 & 101 & 0,29 & 0,51 & 29,68 & 4,37 \\
\hline & $55-110$ & 7,6 & 593 & 98 & 0,19 & 0,88 & 19,88 & 3,55 \\
\hline
\end{tabular}




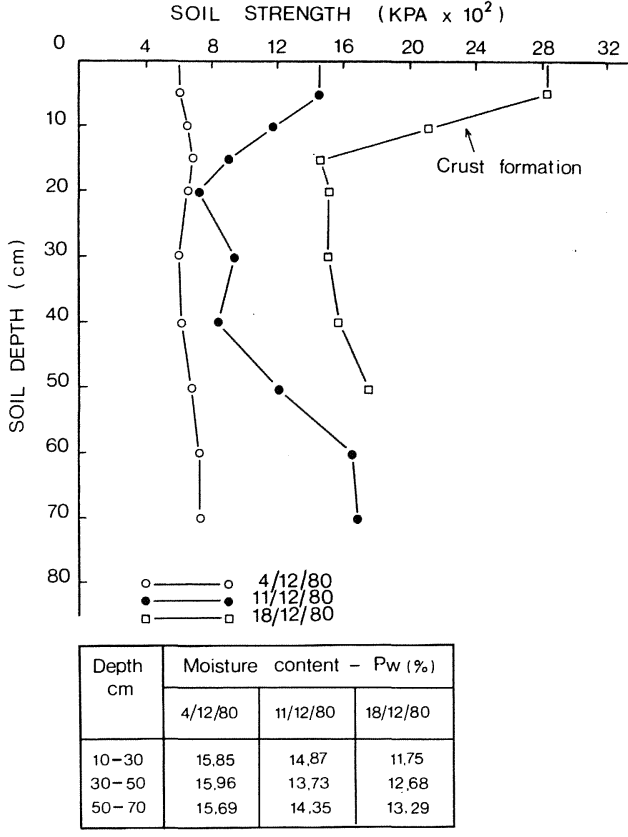

FIGURE 7

Change in soil strength with drying of a Hutton soil at Robertson.
TABLE 6

Yield record of a Colombar/99R vineyard - Bonnievale

\begin{tabular}{lll}
\hline Year & \multicolumn{2}{l}{ Grape yield $\left(\mathrm{t} \mathrm{ha}^{-1}\right) @ 20^{\circ} \mathrm{B}$} \\
\hline 1973 & 23,83 ) & \\
1974 & 20,66 ) & $\overline{\mathrm{X}}_{1}=20,63$ \\
1975 & $19,15)$ & \\
1976 & 18,86 ) & \\
1977 & $17,63)$ & \\
1978 & $17,43)$ & \\
1979 & $19,39)$ & \\
1980 & $14,58)$ & \\
1981 & $13,70)$ & $\bar{X}_{2}=18,15$ \\
1982 & $13,65)$ & \\
\hline Mean & 17,89 & \\
\hline
\end{tabular}

soil is not clear, but it could not be the only reason for the weaker growth. (The $\mathrm{K}^{+}$-cations comprised almost the same percentage of the total extractable cations for both soils).

PENETROMETER READINGS $(x-A X I S)$ AT SEVERAL INTERVALS $(0-22 M)$ FROM CENTRE OF DEAD AREA

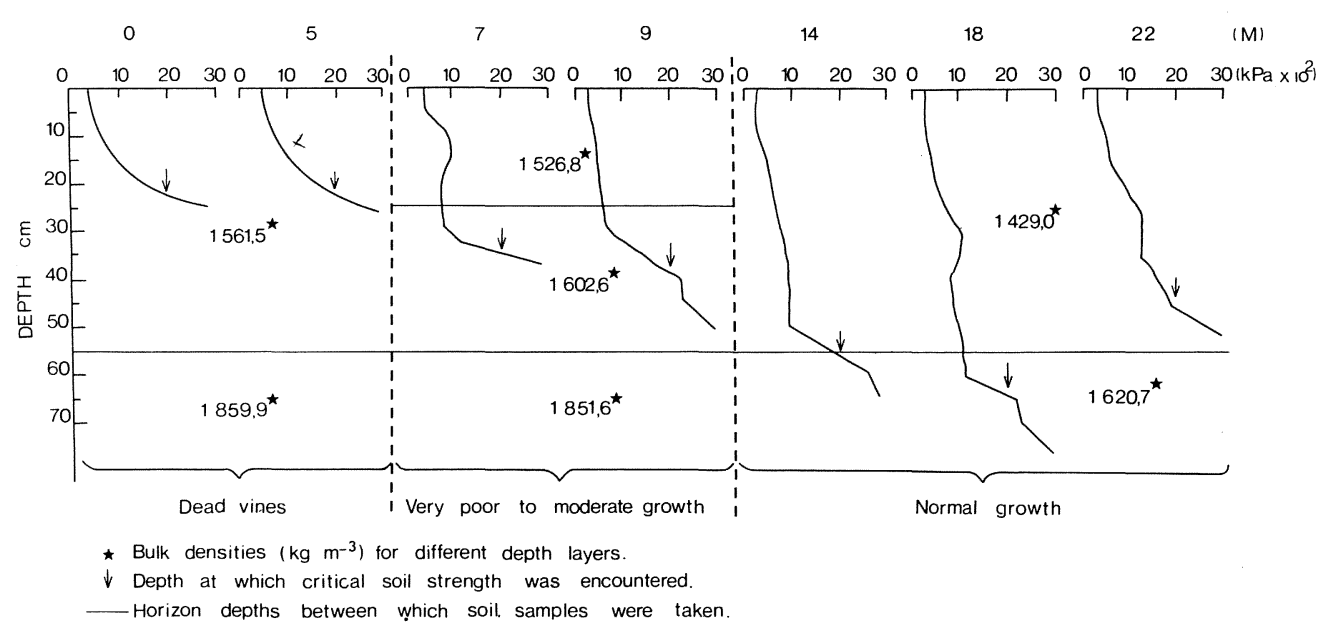

FIGURE 8

The effect of varying degrees of subsoil compaction in a production vineyard near Bonnievale on penetrometer resistance.

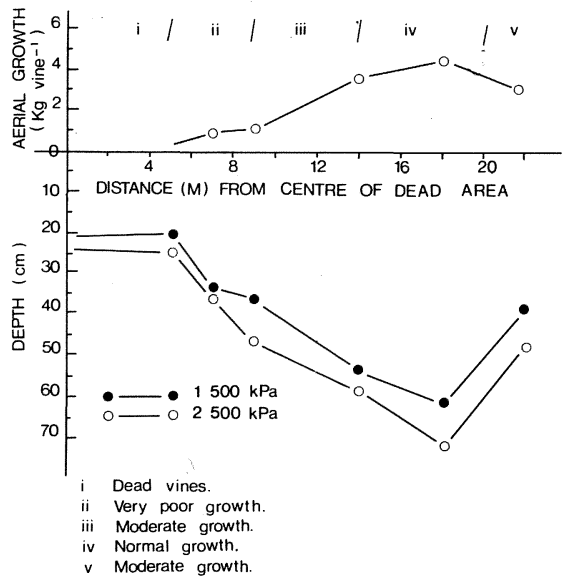

FIGURE 9

The relationship between vine performance and soil depth at which a specific penetrometer resistance was encountered as measured in a production vineyard - Bonnievale.
Penetrometer readings taken at intervals from the centre of dead patches outwards to the unaffected areas are represented in Fig. 8 \& 9. The depth at which the critical soil strength was encountered clearly increased towards the areas with normal growth (Fig. 8). Vine response (vegetative growth) to increasing effective depths are illustrated in Fig. 9. The dead, poorly growing and normally growing vines had similar trunk circumferences (data not shown), showing that soil compaction must have approached a critical level over the last few growing seasons, as was substantiated by yield records of the vineyard (Table 6). There was a $32,2 \%$ drop in average yield over the last three seasons (1980-1982) compared to the average yield during 1973 to 1976 , and $23,0 \%$ decrease compared to the preceding three (1977-1979) years due to generally weaker growth

1) Plant Pathologist - V.O.R.I. 
on the ever enlarging problem patches and an increasing number of dead vines. A plant pathological examination of the dead vines revealed no pathogenes in the roots or the trunks (P. G. Marais, 1982 - personal communication ${ }^{1)}$ ).

The generally weaker growth and death of the vines must, therefore, be mainly ascribed to deleterious effects caused by soil compaction. The relatively high salinity of the compacted subsoil might be due to poor water infiltration and thus poor leaching of salts. The progressive reduction of the available root volume by compaction and/or salinity led to adverse conditions for the remaining roots, such as soil water stress, unfavourable temperatures and poor aeration immediately after irrigation. Supporting evidence is supplied by Saayman (1973) who, after an intensive investigation of the soils of the Bonnievale area, also concluded that vine performance was mostly affected by soil physical conditions, and that in general soil chemical characteristics were important only in as far as they affected the soil structural conditions. In this case the penetrometer proved to be most useful in assessing the soil physical conditions.

\section{CONCLUSIONS}

The effects of various cultivation and soil preparation practices can be assessed by measuring soil strength characteristics with a portable recording penetrometer under field conditions. Zones of high compaction seemed to be quite common in the vineyards investigated and were due either to ineffective soil preparation techniques or to recompaction because of injudicious cultivation practices. The position (vertical) as well as the extent (horizontal) of compaction can be determined with the penetrometer. The penetrometer gave additional information to bulk density values and can as such give added meaning to root studies. Because of the dependence of penetration resistance on soil variables such as texture, density and moisture content, measurements must be made under strictly defined conditions to be useful for studying soil compaction and/or root distribution. Against this background it seems most important that the relationships between soil strength and root penetration for vines must be quantified in future research.

\section{LITERATURE CITED}

AMERICAN SOCIETY OF AGRICULTURAL ENGINEERS (ASAE), 1969. Soil cone penetrometer. ASAE Recommendation R. 313. Agricultural Engineers Handbook.

BAR-YOSEF, B. \& LAMBERT, J. R., 1981. Corn and cotton root growth in response to soil impedance and water potential. Soil Sci. Soc. Am. J. 45, 930-935.
BRADFORD, J. M., 1980. The penetration resistance in a soil with well-defined structural units. Soil Sci. Soc. Am. J. 44, 601-606.

CARTER, L. M., 1967. Portable recording penetrometer measures soil strength profiles. Agricultural Engineering 48, 348-349.

CASSEL, D. K., BOWEN, H. D. \& NELSON, L. A., 1978. An evaluation of mechanical impedance for three tillage treatments on Norfolk sandy loam. Soil Sci. Soc. Am. J. 42, 116-120.

CASSEL, D. K. \& NELSON, L. A., 1979. Variability of mechanical impedance in a tilled one-hectare field of Norfolk sandy loam. Soil Sci. Soc. Am. J. 43, 450-455.

DAVIDSON, D. T., 1965. Penetrometer measurements. In: C. A. Black (ed.), Methods of soil analysis. Part I Agronomy 9: 472-484. Am. Soc. of Agron., Madison, Wisconsin.

EAVIS, B. W. \& PAYNE, D., 1970. Soil physical conditions and root growth. In: W. J. Whittington (ed.), Root growth. 315-338. Butterworths, London.

GILL, W. R. \& VANDEN BERG, G. E., 1968. Soil dynamics in tillage and traction. Agriculturâl Handbook No. 316, ARS USDA. Government Printing Office, Washington.

GREACEN, E. L., BARLEY, K. P. \& FARRELL, D. A., 1969. The mechanics of root growth in soils with particular reference to the implication for root distribution. In: W. J. Whittington (ed.), Root growth. 256-269. Butterworths, London.

MAC VICAR, C. N. \& SOIL SURVEY STAFF, 1977. Soil classification - A Binomial system for South Africa. Scientific Pamphlet 390, Government Printer, Pretoria.

MARSHALL, T. J. \& HOLMES, J. W., 1979. Soil physics. Cambridge University Press, Cambridge.

SAAYMAN, D., 1973. Grondeienskappe en wingerdprestasie in die Bonnievale omgewing. M.Sc. (Agric.)-thesis, Univ. Stellenbosch, Stellenbosch.

SAAYMAN, D. \& VAN HUYSSTEEN, L., 1980. Soil preparation studies: I. The effect of depth and method of soil preparation and of organic material on the performance of Vitis Vinifera (var. Chenin blanc) on Hutton/Sterkspruit soil. S. Afr. J. Enol. Vitic. 1(2), 107-121.

SAAYMAN, D. \& VAN HUYSSTEEN, L., 1981. The efficiency of different methods of lime application during soil preparation. S. Afr. J. Enol. Vitic. 2(1), 29-35.

SCHULTE-KARRING, H., 1976. Bodenschäden und massnahmen zu ihrer behebung: Aufgezeigt an beispielen aus dem Südafrikanischen weinbau. Der Deutsche Weinbau 31(25), 941-943.

TAYLOR, H. M. \& BURNETT, E., 1964. Influence of soil strength on the root growth habits of plants. Soil Sci. 97-98, 174-180.

TAYLOR, H. M. \& GARDNER, H. R., 1963. Penetration of cotton seedling taproot as influenced by bulk density, moisture content and strength of soil. Soil Sci. 96, 153-156.

TAYLOR, H. M., ROBERTSON, G. M. \& PARKER, J. J. (Jnr.) 1966. Soil strength-root penetration relations for medium to coarse textured soil materials. Soil Sci. 102, 18-22.

VAN HUYSSTEEN, L. \& SAAYMAN, D., 1980. A promising locally developed vineyard subsoiler. Wynboer 586(7), 56-59.

VAN HUYSSTEEN, L. \& WEBER, H. W., 1980. The effect of conventional and minimum tillage practices on some soil properties in a dryland vineyard. S. Afr. J. Enol. Vitic. 1(1), 35-45.

WALDRON, L. J. \& CONSTANTIN, G. K., 1970. Soil resistance to a slowly moving penetrometer. Soil Sci. 109, 221-226.

ZIMMERMAN, R. P. \& KARDOS, L. T., 1961. Effect of bulk density on root growth. Soil Sci. 91-92, 280-288. 